\title{
Establishing factors of building vulnerability towards tsunami hazard
}

\author{
Leli Honesti ${ }^{1 *}$, Muhd Zaimi Abd Majid ${ }^{2}$, Nazwar Djali ${ }^{3}$, Meli Muchlian ${ }^{1}$ \\ ${ }^{1}$ Department of Civil Engineering, Faculty of Civil Engineering and Design, Institut Teknologi Padang, Indonesia \\ 2 Department of Structure and Material, Faculty of Civil Engineering, Universiti Teknologi Malaysia, 81310 UTM Johor Bahru, \\ Johor, Malaysia \\ 3 Department of Civil Engineering, Faculty of Civil Engineering and Design, Bung Hatta University, Indonesia
}

\begin{abstract}
The objective of this article is to establish the attributes (factors) of building vulnerability towards tsunami hazard, particularly for areas in Padang, Indonesia, as well as those areas with the same characteristics. Within this framework, this study informs the progress towards a more systematic approach to factor development for a Relative Vulnerability Index (RVI) score for assessing the building vulnerability towards tsunami hazard. The RVI score is used to predict tsunami risk zones on building vulnerability. The analysis was conducted to develop the factors that influence the building vulnerability. Developing factors of the building vulnerability to tsunami hazard is a key aspect for assessing the RVI, as their result may misguide local decision-makers to act adequately concerning the local risk if they are based on an inappropriate set of factors. These factors were classified under three distinct groups: 1) internal factors; 2) external factors and 3) water inundation factor. The selection of factors are based on the building and the location characteristics. Therefore, the factors that may influence the risk were listed. Based on the kinds of literature and opinion of practitioners/experts, several imperative factors that affect the risk were identified and studied. The factors were tabulated and were sorted from highest to lowest numbers. Based on the tabulation of these factors, the summary of analysis results for internal factors are: construction material; the number of stories; foundation type; date of the building; preservation condition; ground floor hydrodynamic; shape and orientation of the building. Furthermore, based on the tabulation results for external data factors and tsunami inundation factor, the external factors are: movable object; building row; height of concrete fence; natural barrier; distance from the coastline; distance from the river; obstacle islands and gap between building attributes and water inundation factor is tsunami inundation depth.
\end{abstract}

Keywords: Internal factors, external factors, water (tsunami) inundation factor

Corresponding author: leli.honesti@itp.ac.id 


\section{Background}

There are many countries in this world that are located within the areas where the tectonic plates are active. Most of these coastal areas are vulnerable to tsunamis. When tsunami occurs, the forces released are in the form of hydrodynamic pressure, erosion (scouring), buoyancy, as well as the effect by objects and debris carried by the water [29].

Padang being a populous area, is very vulnerable to earthquakes and tsunamis because the region is near a seismic source in Mentawai Islands. The city is located on the west coast of Sumatra Island. It faces the open Indian Ocean. The Mentawai Islands is part of the territorial sea. The city has also five large rivers including Batang Kuranji, Batang Air Dingin, Batang Logam, Batang Kandis and Batang Tarung. The rivers run through Padang to the sea.

Honesti et.al., in 2015 [18] investigated Pasir Jambak and Ulak Karang sub-districts in Padang. These two sub-districts are located at 0.860-0.864 south latitude and 100.328-100.345 east longitude for Pasir Jambak and at 0.912-0.915 south latitude and 100.354 east longitude for Ulak Karang. They face with the Islands of Mentawai. The characteristics of two coasts are low-lying area and sandy beach. Those types also extend along the coast of Padang. The higest tsunami water inundation generally occurs in sandy coast [52]. The communities of Pasir Jambak and Ulak Karang have densely populated areas and different kind of buildings.

Because most inhabitants subsist in this subdistricts and along the shore of Padang, many community activities and public services are available, such as Bung Hatta University, Padang State University, Markets, and Schools. These coasts are very vulnerable to seismics and tsunamis, causing extensive vulnerability to the buildings, infrastructures, and facilities.

The problem in assessing the building vulnerability to tsunami hazard occurs in Padang, as some of the existing parameters or attributes for assessing the risk are not suitable to be applied. This is mainly due to the fact that there are uncertainties of attributes in the models for the building vulnerability as well as the physical area characteristics of West Sumatra, Indonesia. To improve the attributes, the factors of building vulnerability towards tsunami hazard were developed.

The suite of attributes, which are reported influencing the damage degree or protection towards tsunami inundation for individual buildings and structures, were identified by Papathoma (2003) [37] based on an analysis of the survey of multiple posttsunami field. These attributes were grouped into some major classes or classifications: built environment, sociological data, economic data, and environmental/ physical data and variations in the degree or range of these attributes were identified together with a vulnerability indicator for each attribute. DomineyHowes in 2007 [14] have established the PTVA model. They develop the original model by validating the characteristic of water in the fields. Then, in 2009
Dall'Osso et al. [10] have established the Papathoma Tsunami Vulnerability Assessment (PTVA-3) model, an improved version that takes count of understanding factors that influence the vulnerability of building and use the Analytic Hierarchy Process (AHP) for weighting the various factors.

The aim of this study is to analyze the attributes (factors) for estimation of Relative Vulnerability Index (RVI) scores for building vulnerability towards tsunami hazard. These investigations can be useful to provide the factors, based on the characteristics of the buildings and spesific geographical features of the area. Such characteristics are very important for RVI scores of the risk. Here, RVI scores are used to predict tsunami risk zones on building vulnerability.

\section{Methods}

In this study, the factors of building vulnerability towards tsunami hazard were applied to inside and outside of each building. The factors referred to the building condition called internal factors, out of the building condition called external factors and water (tsunami) inundation factor.

To provide the attributes or factors, the following methodological steps are undertaken :

1. Identification of factors that affect the vulnerability of the building. The factors were modified by inserting some vulnerability factors of building depending on the characteristics of the buildings and the specific geographical features of Padang. As an investigation for the building vulnerability, this study established the building vulnerability factors based on internal and external factors and water inundation factor. Characteristics of the chosen factors were also developed from the PTVA-3 model as well as a number of literature by experts in the field. For example, some experts stated that the existence of a barrier island, distance from the river, gaps between buildings and distance from the shoreline affect the building vulnerability towards tsunami effects.

2. Tabulation data for vulnerability factors within the inundation zones by finding the most often used by researchers in previous studies.

3. Selection of building vulnerability factors which the most commonly used by researchers.

In the PTVA-3 model, the factors of vulnerability consist of structural vulnerability and water (tsunami) inundation vulnerability. The structural vulnerability is assigned by the building vulnerability factors (BV) and protection factors (Prot). The factors of building vulnerability (BV) include: 1) number of stories; 2) building material; 3) ground floor; 4) foundation; 5) shape and orientation of building; 6) movable object and 7) preservation condition. The factors of protection on the other hand contain 1) building row; 2) natural barrier; 3) seawall height and shape, and 4) brick wall around the building. 
The formula of the PTVA-3 model is as follow:

$\mathrm{RVI}=(2 / 3) \times\left(" \mathrm{SV} \_1 \_5 "\right)+(1 / 3) \times\left(" \mathrm{WV} \_1 \_5 "\right)$

where "SV 15 " is the structural vulnerability and "WV_1_5" is the water vulnerability [10].

\section{Results dan Discussion}

Hajar (2006); Jelínek et al. (2009); Dall’Osso and Dominey-Howes (2009); Dall'Osso et al. (2009); Sumaryono (2010); Atillah et al. (2011); Barros et al. (2015) and Sivakumar and Sivagamasundari (2015) [16, $23,10,46,2,4,44]$, have taken the attributes related to the vulnerability of building to tsunamis. Based on the tabulation data, Table 1 depicts the internal factors for building vulnerability.

In detail, IF1 is building materials/construction materials, IF2 is number of floors/number of stories, IF3 is date of built/ building age, IF4 is preservation condition, IF5 is hydrodynamics of $\mathrm{r} / \mathrm{c} /$ ground floor hydrodynamic, IF6 is existence of underground floors, IF7 is foundation types/foundation strength, IF8 is occupation form, IF9 is number of utilization units, IF10 is the average number of daily visitor or residents per unit of use and IF11 occupation floating, IF12 is built form plan, IF13 is emerged building height in relation to the wave, IF14 is description of ground floor, IF15 is shape and orientation/ building orientation/building geometry. The tabulation of internal factors for the building vulnerability was identified to provide the highest and lowest numbers, as presented in Table 2.

Table 3 is the tabulation of external factors and water inundation factor for the building vulnerability.

The results of external factors and water (tsunami) inundation depth factor from highest to lowest, are presented in Table 3. Moreover in detail, EF1 is distance from the sea/distance to coastline, EF2 is ground elevation, EF3 is row position/ building row, EF4 is movable objects, EF5 is morphology of the flooded area, EF6 is consolidation of geologic materials, EF7 is average slope $\left({ }^{\circ}\right)$, EF8 is use and land cover, EF9 is the emerged building height in relation to the wave, EF10 is sea defence/ sea wall height and shape, EF11 is natural environment/ natural barrier, EF12 is brick wall around the building, EF13 is tsunami inundation; EF14 is land cover, EF15 is shore morphology, EF16 is distance from the river and EF17 is an obstacle islands.

The existence of an obstacle Island needs to be considered in order to determine the building vulnerability. Here, Khasanah et al., 2014 [26] stated that an island barrier is effective in reducing tsunami energy. Gap between buildings which was originally not in the tabulation data has been added as the attribute which is closely related to building vulnerability. The gap between buildings reduces the impact of a tsunami as it hampers the tsunami energy $[3,6]$.

Table 1. Tabulation of internal building factors

\begin{tabular}{|c|c|c|c|c|c|c|c|c|c|c|c|c|c|c|c|}
\hline \multirow[t]{2}{*}{ Author } & \multicolumn{15}{|c|}{ Internal Factors (IF) } \\
\hline & 1 & 2 & 3 & 4 & 5 & 6 & 7 & 8 & 9 & 10 & 11 & 12 & 13 & 14 & 15 \\
\hline Sivakumar et al. (2015) & $\sqrt{ }$ & & & $\sqrt{ }$ & & & & & & & & & & & \\
\hline Barros et al. (2015) & $\sqrt{ }$ & $\sqrt{ }$ & $\sqrt{ }$ & $\sqrt{ }$ & $\sqrt{ }$ & $\sqrt{ }$ & $\sqrt{ }$ & $\sqrt{ }$ & $\sqrt{ }$ & $\sqrt{ }$ & $\sqrt{ }$ & $\sqrt{ }$ & $\sqrt{ }$ & & \\
\hline Atillah et al. (2011) & $\sqrt{ }$ & $\sqrt{ }$ & & & & & & & & & & & & & \\
\hline Sumaryono (2010) & $\sqrt{ }$ & $\sqrt{ }$ & $\sqrt{ }$ & & & & $\sqrt{ }$ & & & & & & & $\sqrt{ }$ & $\sqrt{ }$ \\
\hline Dall'Osso et al.(2009) & $\sqrt{ }$ & $\sqrt{ }$ & & $\sqrt{ }$ & $\sqrt{ }$ & & $\sqrt{ }$ & & & & & & & & $\sqrt{ }$ \\
\hline Jelínek et al.(2009) & $\sqrt{ }$ & $\sqrt{ }$ & & & & & & & & & & & & & \\
\hline Hajar, M (2006) & & & & & & & & & & & & & & & \\
\hline Total & 6 & 5 & 2 & 3 & 2 & 1 & 3 & 1 & 1 & 1 & 1 & 1 & 1 & 1 & 2 \\
\hline
\end{tabular}

Table 2. Total internal factors

\begin{tabular}{llc}
\hline No & \multicolumn{1}{c}{ Internal Factors } & Total \\
\hline 1 & Building material/construction material & 6 \\
2 & Number of floors/number of stories & 5 \\
3 & Foundations type/foundation strength & 3 \\
4 & Date of built/building age & 2 \\
5 & Preservations conditions & 3 \\
6 & Shape and orientation/ building orientation/building geometry & 2 \\
7 & Ground floor hydrodynamic & 2 \\
\hline
\end{tabular}


Table 3. External building factors and water (tsunami) inundation factor tabulation

\begin{tabular}{|c|c|c|c|c|c|c|c|c|c|c|c|c|c|c|c|c|c|}
\hline \multirow[t]{2}{*}{ Author } & \multicolumn{17}{|c|}{ External Factors (IF) } \\
\hline & 1 & 2 & 3 & 4 & 5 & 6 & 7 & 8 & 9 & 10 & 11 & 12 & 13 & 14 & 15 & 16 & 17 \\
\hline Sivakumar et al. (2015) & $\sqrt{ }$ & $\sqrt{ }$ & $\sqrt{ }$ & $\sqrt{ }$ & & & & & & & & & & & & & \\
\hline Barros et al. (2015) & $\sqrt{ }$ & & & & $\sqrt{ }$ & $\sqrt{ }$ & $v$ & $\sqrt{ }$ & $\sqrt{ }$ & & & & $\sqrt{ }$ & & & & \\
\hline Atillah et al. (2011) & & & & & & & & & & & & & $\sqrt{ }$ & & & & \\
\hline Sumaryono (2010) & & & & $\sqrt{ }$ & & & & & & $\sqrt{ }$ & $\sqrt{ }$ & & $\sqrt{ }$ & $\sqrt{ }$ & & & \\
\hline Dall'Osso et al. (2009) & & & $\sqrt{ }$ & $\sqrt{ }$ & & & & & & $\sqrt{ }$ & $\sqrt{ }$ & $\sqrt{ }$ & $\sqrt{ }$ & & & & \\
\hline Dall'Osso et al.(2009) & & & $\sqrt{ }$ & $\sqrt{ }$ & & & & & & $\sqrt{ }$ & $\sqrt{ }$ & $\sqrt{ }$ & $\sqrt{ }$ & & & & \\
\hline Jelínek et al.(2009) & $\sqrt{ }$ & & & & & & & & & & & & $\sqrt{ }$ & & & & \\
\hline Hajar, M (2006) & $\sqrt{ }$ & $\sqrt{ }$ & & & & & & & & & $\sqrt{ }$ & & & & $\sqrt{ }$ & $\sqrt{ }$ & $\sqrt{ }$ \\
\hline Total & 4 & 2 & 3 & 4 & 1 & 1 & 1 & 1 & 1 & 3 & 4 & 2 & 7 & 1 & 1 & 1 & 1 \\
\hline
\end{tabular}

Table 4. Total external and tsunami flow depth factors

\begin{tabular}{clc}
\hline No & \multicolumn{1}{c}{ External factors } & Total \\
\hline 1 & Tsunami inundation & 7 \\
2 & Distance from sea/distance to coastline & 4 \\
3 & Movable object & 4 \\
4 & Natural environment/ natural barrier & 4 \\
5 & Row position/ building row & 3 \\
6 & Sea defence/ sea wall height and shape & 3 \\
7 & Ground elevation & 2 \\
8 & Morphology of the flooded area & 1 \\
9 & Brick wall around the building & 2 \\
10 & Distance from the river & 1 \\
11 & Obstacle islands & 1 \\
\hline
\end{tabular}

The following is the list of factors that were also investigated for internal factors of building vulnerability:

\section{Construction materials}

The appropriateness of a particular building material can never be underestimated. The local context plays a significant role in determining whether a specific building material is sustainable or otherwise. For example, compressed earth blocks (CEB) may be appropriate in one setting but not in another, depending on the availability of soil of acceptable quality. The quarry of soil must also not jeopardize ecologically sensitive areas, agricultural lands or other livelihood sources [47].

The closeness of Sumatra to major fault zones océan - Australia indicates that the zone is extremely vulnerable to the effects of earthquakes and following tsunamis. The dwellings in the traditional rural housing schemes in Sumatra have mainly been constructed using timber, particularly in the rural and the more remote areas. In coeval Aceh, there is an option for using bricks as the principal construction material. In such a condition, wood materials using non-stiff connection is most suitable. In towny and subur regions, however, there has been a significant transformation to the use of masonry as the primary construction material, with timber primarily being used for frames of roof, casement and door and floors. Even though wood can be denied to be more suitable climatically and more reactive to the general circumstances of quakes, there is an intense society comprehension that a masonry dwelling is more persistent and needs less preservation. Construction with masonry is also apprehended as "contemporary" or as a symbol of social position and fortune. Building construction team needs to be conscious, of this modern perception, especially where option building materials are being promoted. The recognition of aluminium and steel for roof joining and doors and frames of the window can give an option to wood [47].

The greater number of buildings that collapsed in Banda Aceh and Meulaboh are non engineered construction containing two types. The first type is of one or two stories buildings made of burnt brick confined masonry using sand and portland cement mortar. The roof mostly consists of galvanized iron sheets. All those buildings used RC "practical" columns and beams as confinement. The second type is of timber construction consisting of a timber frame as well as timber planks walls, and in most cases use galvanized iron sheets as the roof [8].

The main construction material categories of a building influence the levels of building vulnerability. The observation in the field on building materials was implemented based on four categories: namely wood, wood + concrete, traditional brick, reinforced concrete with the brick infill walls, and concrete + steel. The levels of damage to buildings were found principally related to the construction type $[37,14,12,15,31,40$, 41]. In observational studies, it was found that the most resistant structures are made from reinforced concrete and double or single bricks. 
Matsutomi et al. (2010) [31] identified that timber buildings and construction in Japan earthquakes will be absolutely damaged at a shuffle force from 9.7 to $17.6 \mathrm{kPa} / \mathrm{m}$, which conforms with an tsunami water depth of $2 \mathrm{~m}$ and a velocity of $2.9 \mathrm{~m} / \mathrm{s}$. For stone and brick buildings, the thresholds lie at $118-215 \mathrm{kPa} / \mathrm{m}$, or 7 $\mathrm{m}$ tsunami water depth and $5.5 \mathrm{~m} / \mathrm{s}$ velocity successively. It can be seen that the differences may not only occur between countries, but also the different regions within a country such as New Zealand. In order to apply this loading approach, one would have to define a typical house for each category. However, due to variations in construction methods and techniques, quality of workmanship, ignorance of building codes and standards, deterioration, etc., most buildings, even of the same type and material, will have different strengths. Ideally, this approach should quantify the range of strengths that similar sorts of buildings could withstand. This would explain part of the uncertainty encompassed in the fragility functions.

\section{Number of stories}

Multistory hotel buildings that are built on a concrete frame and/or steel structures, and meet the seismic standard and building codes are the potential locations to be a vertical tsunami evacuation building. As a vertical evacuation building, the hotel structure must not only withstand the preceding earthquake with minimal damage and remain functional but also has to withstand the tsunami wave and debris it carried. Therefore, it is important to first assess the hotel structure to be sure that it can serve as an evacuation building. Commonly the third floor and above of an evacuation building can be considered as a safe place for refuge, however, it is also dependent on the estimated tsunami inundation depth of the area [48].

Given the uncertainty involved in tsunami modeling and estimation, if the first story height is set unconservatively low, the water run-up could potentially exceed the first story height, wash away the contents in the second story, and pose buoyancy and hydrodynamic uplift force on the $2^{\text {nd }}$ floor concrete slab, as well as the excess moments on the column structures. Thus, the design team must exercise care to properly set the height for the first story [37]. Almost none of the people's housing, of one to two story masonry buildings that have collapsed by the shaking, even though some had cracks in the walls. The destruction was caused by tsunami forces (Boen, 2005) [8]. The multi-storey buildings need more resistant load as compared to single-storey buildings due to the fact that the scores of building are calculated based on the factor of load-bearing capacity $[37,12,14,40]$.

\section{Foundation types}

The observation on the field towards foundation was carried out in order to obtain the foundation types of the building. Buildings with deep foundations can withstand more effectively the scouring effect of the tsunami inundation and can resist the impact of tsunami, but shallow foundations endure the heaviest levels of damage $[37,12,14,40]$.

\section{Date of building}

Post-tsunami surveys have shown that many of the old buildings have collapsed during the tsunami $[10$, 46].

\section{Preservation condition}

Rearing and caring for a building are associated with the safety, health, comfort, and ease of a building (Indonesia, 2008) [21]. Hot, damp, tropical conditions, or alternating dry and rainy weather, combine with the constant threat of insects, industrial pollution, and a low level of building maintenance creates serious environmental challenges to the preservation of these holdings (Beck, 1999) [5].

Both public and private owners have come to realize the economic benefits of preservation. Savings in costs, materials, and energy in the adaptive reuse or preservation of existing buildings are significant. In adaptive reuse projects, the cost per square foot can be substantially less than that of a new construction. In addition, both the energy and the natural resources can be saved by reusing existing structures rather than manufacturing, delivering, and constructing buildings with new materials [1]. A building a poor state of preservation usually is expected to suffer heavier damage, especially if there are structural failures [14, 40].

\section{Ground floor hydrodynamics}

The structural columns of a building must be vertical, must be constructed before the wall construction, must be made in one part, and must be integrally connected to the foundation [49]. The lowest story should be an open space on the ground floor to allow for water and debris passage. Or, the lowest floor may be designed to be sacrificial, such as with breakaway walls. The elevation of the bottom of the second story should be higher than the anticipated tsunami inundation elevation [39].

Based on the investigations of the effects of the 2004 Indian Ocean tsunami on buildings in Thailand, it was found that buildings with an open plan ground floor and/or open-breakable (such as windows, doors) are less vulnerable to the impacts of waves, allowing the wave to pass through the ground floor and this absolutely minimizes the structural failure [12]. Based on the field survey on the condition of ground floor, it was found that they can be categorized into five levels; namely the: not-opened plan, not-opened but many windows; 50\% opened-plan; opened plan \& windows and opened plan.

\section{Shape and orientation of the building}

Following the 2004 tsunami, it was found in many field surveys that buildings which have specific shapes (e.g., hexagonal, triangular, rounded, etc.) endure lighter failures than those long rectangular or"L" shaped buildings whose main wall is oriented perpendicular to the direction of flow $[50,14]$. In this study, the building orientation was identified by the image of the satellite from the longest side of each building and the observation of the building orientation towards the coastlines. Consequently, the buildings which are 
oriented parallel to the direction of coastlines are more in danger than the buildings which are oriented perpendicular towards the coastlines. During the July 2006 Java tsunami, most of the dwellings in four villages, namely the Ciliang, Cikembulan, Wonoharjo and Pananjung, have been severely damaged, with a big number of casualties and injuries, and this is believed to have been attributed to the fact that the building clusters were laid out parallel, rather than perpendicular to the beach [40].

The list of the attributes was needed to develop the external factors for building vulnerability as shown below:

\section{Movable objects}

The losses of some movable and unmovable objects increase even after the physical hazard process reaches to an end if the relief actions are not immediate and efficient $[43,45,28]$. During the inundation of a tsunami, movable objects, such as cars, debris, boats, and even trucks, will be dragged around by the flowing water and pushed against buildings and constructions, causing severe structural damage [37, 12, 37, 40].

\section{Building row}

Post-tsunami surveys have shown that buildings located near the coast become are more exposed to threats as compared to those which are situated far from the coast. One factor which is also important in the case of the protection of building towards from the pressure of tsunami wave is the number of other structures located between a building and the coastline. After tsunami survey shows that the buildings located in the line near the coast become protection for the buildings which are located more the inland [35, 14, 37].

The wave of tsunami that hitting the shores carries energy which consists of kinetic energy due to the wave speed and potential energy due to its height. Buildings of the first rank then fully experience the shock wave and help to dampen its energy as it moves to further ranks. Therefore, buildings of the first row are exposed to a greater risk. The other buildings received minor shocks according to their rank from the shore [7].

\section{The Height of concrete fence}

A fence is used as bulkhead made of wood, bars, bricks or concrete. Generally, a fence is distinguished by the construction strength. In tsunami vulnerability, the concrete fence is a component to protect the buildings for inundation and material carried by tsunamis. In this research building fence are grouped in three types; namely concrete wall, concrete wall modification, and wood/bamboo or without a fence. The concrete wall with height $<1$ meter is included in the modification wall [36].

After the investigation of concrete masonry garden walls in the Miyagi prefecture that collapsed, it was found that there are several factors that contribute to the fall, namely due to ground deformation; collapse of unreinforced portions of walls due to poor construction; tip-over and collapse due to insufficient anchorage of vertical reinforcing bars into foundations or due to insufficient embedding of the foundation into ground; collapse due to reinforcing bar corrosion; major cracking at lap splice joints along the horizontal top reinforcing bar; and tsunami-induced overturn and collapse. The investigation of a certain district in Natori showed that $16 \%$ of the concrete masonry garden walls and many of the non-reinforced stone masonry garden walls have collapsed during the tsunami [26].

A building which has concrete fence or brick wall, (around the building), will be more protected as compared to the ones that do not have the concrete fence. The risk of building vulnerability depends on the height of the fence $[14,40]$. Individual walls located around the building structures (such as garden walls), although not specifically constructed to provide protection from flooding, do offer some protection from flood inundation [14].

\section{Natural barriers}

One of the most common protection found in studies are the natural barriers, which are referred to as a naturally occurring obstacle to protect buildings from tsunamis. Trees, mountains, deserts and ice fields are among the clearest examples of natural barriers. The existence of a natural barrier in front of the sea such as trees, sand dunes or cliffs etc. reduces the force of a tsunami wave. This attenuation is expressed by a decrease in several wave parameters such as the tsunami height. This phenomenon becomes more important as the barrier height is greater. Therefore, the flooding hazard decreases with the height of a natural barrier, making it one of the most significant protection means [7].

Coastal forests, with mangrove, sago palm, casuarinas tree and, coconut tree, are known for their natural functions to reduce tsunami force, and it is an alternative solution to overcome the weaknesses of artificial measures [24]. Mangroves tolerated the December 26 tsunami, 2004 waves without showing any apparent damage, therefore, they are considered as the most suitable species to mitigate the effects of mighty tidal waves [25].

\section{The presence of a seawall}

Seawalls, usually built to protect against storm surges and high tides, can also give protection during a tsunami. Based on the historical records of the 2004 tsunami in Thailand, the building damage was significantly lower in places protected by sea defense [12]. In fact, in places where no sea defense stand (for example, to allow pedestrian access to the coast), damage to buildings was higher. The design of the seawall was also important. In this case, there appeared to be no protective effect from the seawall to the buildings located landward of the wall [12].

6. Distance from the shoreline

Distance from the shoreline is referred to the likely extent of the tsunami inundation. In general, vulnerability becomes higher when shoreline distance decreases. Najihah et al. (2014) [33] classified the distance from the coastline into five categories namely: 0-100 m (Very High), 100-200 (High), 200-300 (Medium), 300-400 (Low) and 400-500 (Very Low) 
[30]. As part of the measures for the mitigation of tsunami hazard, it is highly recommended for people to avoid building or living in buildings within 200 meters of the high tide coastline. These areas are more likely to experience damage from tsunamis, strong winds, or coastal storms [35].

The tsunami waves with run-up as high as from 5 to $12 \mathrm{~m}$ which have once occurred in Aceh, could get into the land to as far as $8 \mathrm{~m}$. Based on the considerations above, this research attempts to classify the distance from the coastline as part of the factors for building vulnerability $[17,18]$.

\section{Distance from the river}

As seen from the coastline to the land, many areas near the coast have a high vulnerability to tsunami disaster due to the fact that it is near the river and canal, and the rivers are quite near the coastline. The river near the coastline will increase the velocity from the lunge of tsunami waves, which consequently will endanger the areas near the river.

When a tsunami propagates to the canal, the tsunami causes damage of infrastructure in the coastal area even though it is far away from the shorelines. For example, tsunamis in California passed the flood control channels and entered the mainland to as far as 1.609 square kilometers or more, which occurred at high tide [34].

Tsunami waves arrive first in the shoreline, estuary, and the river. Then, they enter the city through the rivers, canals, or by destroying the settlements in the shores. These different geographical characteristics can be divided into the coastal, riverfront, and inland areas (Hajar, 2006) [16]. Hajar (2006) [16] has divided the distance from the river factor into ten classes. An area which is close to the river is more vulnerable to inundation. Many cities have rivers near their estuaries and many rivers are located facing one another. The condition of the river will cause the area located between the rivers which face one another to have high vulnerability level $[17,18]$.

The northern part of Padang city has many more rivers as compared to the part in the south. Therefore, the northern part of the city is more vulnerable as compared to the southern part.

\section{Obstacle Islands}

The obstacle island is one of several attributes (external factor) that could reduce building vulnerability. The factor was derived from a literature review of tsunami histories in several areas in Indonesia, scientific justification, as well as discussions with experts of the tsunami. The existence of obstacle islands acts as barriers for a coastal area and reduces its vulnerability to tsunamis. The existence of obstacle islands needs to be considered to determine the building vulnerability [16].

The distance, form, and size of islands determine the levels of tsunami risk. Nusakambangan Island, a barrier island, decreases the tsunami forces in north Cilacap. The barrier Island is effective in reducing tsunami energy [26]. Based on the tsunami that took place in Flores in 1992, the waves from the northwest of three minutes have hit the northern coast of Sikka. The regions protected by the barrier island were not so severely damaged. In the Flores islands, the barrier island was the one that suffered the most damage when tsunami hazard occurred. The form of this island has caused the trapping of waves to occur. The waves also through went refraction and diffraction [13].

\section{Gap between buildings}

Rows of similar buildings (houses or dwellings) with space or gaps in between are a common feature in the newly designed residential complex, an approach which was also taken in Aceh in its reconstruction following the tsunami disaster in 2004. In this case, tsunami waves may penetrate the building complex through the gaps whilst at the same time the buildings reflect the waves to create backwater. The gaps perform a significant part in reducing the inundation and therefore generate backwater. Smaller gaps subside more energy of wave forces of tsunami and the obverse buildings may be considered as defense to the rearward buildings. However, smaller gaps create higher backwater which subsequently adds to the drag force on the front buildings. Tsunami force on buildings depends on the surrounding area such as the adjacent buildings. The gaps between buildings have prominent impacts on the contribution of inundation energy/force [6]. The spacing between buildings can consequently reduce the loads on the walls and structure of the building. Therefore it is highly recommended to observe adequate distance between the buildings in the site [3].

The local authority regulation of Simelue, Aceh Province No.6, 2008 on buildings, have stated that free space between residential buildings should be: a) at least $4 \mathrm{~m}$ for a different parcels; b) at least $3 \mathrm{~m}$ for the same parcels and c) at least $1 / 2$ building height for residential buildings with the height of more than $8 \mathrm{~m}$. The buildings which are located close to each other will experience heavy damage [17].

\section{Conclusion}

Compared to the building vulnerability in other researchers, every researcher used the factors/attributes that are different compared to the others. Here, with the result that the writers combined several factors by selecting the factors that contribute greatly to the building vulnerability due to tsunami hazard in Padang, West Sumatra, Indonesia and as well as those locations with the same characteristics.

Based on the result of tabulation and selection of building vulnerability factors in this research, there are some differences of factors used by every expert in the previous researches. This is due to the fact that many factors used have significant influence for building vulnerability, but several factors do not choose because the factors do not influence significantly in an area.

Furthermore, based on the investigation and tabulation of building vulnerability factors, it can be concluded that the three major factors which chosen in this study are: first, 1) construction materials; 2) number 
of stories; 3) foundations types; 4) preservation condition; 5) building age; 6) ground floor hydrodynamics; 7) shape and orientation of the building as internal factors, second, 1) movable objects; 2) building row; 3) height of concrete fence; 4) natural barrier; 5) the presence of a seawall; 6) distance from the shoreline; 7) distance from the river; 8) obstacle islands and 9) gap between buildings as external factors and third, tsunami inundation depth as water inundation factor.

\section{References}

[1] AIA. (2001). Guide to Historic Preservation. The American Institute of Architect

[2] Atillah, A., Hadani, D. El., Moudni, H., Lesne, O., Renou, C., Mangin, A., and Rouffi, F. (2011). Tsunami vulnerability and damage assessment in the coastal area of Rabat and Sal'e, Morocco. Natural Hazards Earth System Sciences. Vol. 11, pp. 3397-3414. Copernicus Publications on behalf of the European Geosciences Union.

[3] Arkedani, A and Hosseini, M. (2012). Urban and Architectural Approaches to Design Against Tsunami. 15 $5^{\text {th }}$ World Conference on Earthquake Engineering (WCEE). Lisboa.

[4] Barros, J. L., Emídio, A., Santos, A., and Tavares, A. O. (2015). Composite methodology for tsunami vulnerability assessment based on the numerical simulation of 1755 Lisbon tsunami-application on two Portuguese coastal areas. In Nowakowski, T. et al. (Eds). Safety and Reliability: Methodology and Applications. pp. 1581. London: Taylor \& Francis Group.

[5] Beck, I. (1999). Building Preservation Knowledge in Brazil. Washington, D.C. Council on Library and Information Resources

[6] Benazir, Triatmadja, R., Yuwono, N., Nurhasanah, A., and Kuswandi. (2013). Tsunami Force on Low Building and the Effect of Surrounding Buildings. Proceedings of the $7^{\text {th }}$ International Conference on Asian and Pacific Coasts (APAC 2013), September 24-26. Bali, Indonesia.

[7] Bendaoui, Kh., Hammoumi, A. El., Gueraoui, K., Kerroum, M., Elghachi, M., Ghouli, A., Cherraj, M., Brahim, A. I., Mouraouah, A. E., (2010). The vulnerability of Buildings for a Tsunami. International Review of Mechanical Engineering (I.RE.M.E.). Vol. 4, No. 5. Praise Worthy Prize S.r.l.

[8] Boen, T. (2005). Sumatra Earthquake 26 Dec 2004. https://www.eeri.org.

[9] Budiarjo, A. (2006). Evacuation Shelter Building Planning for Tsunami-prone Area; a Case Study of Meulaboh City, Indonesia. Master of Science, International Institute for Geo-information Science and Earth Observation, Netherlands.

[10] Dall'Osso, F., Gonella, M., Gabbianelli, G., Withycombe, G., and Dominey-Howes., D. (2009). A revised (PTVA) model for assessing the vulnerability of buildings to tsunami damage.
Natural Hazards Earth System Sciences. Vol. 9, pp. 1557-1565. Copernicus Publications on behalf of the European Geosciences Union.

[11] Dall'osso, F., Gonella, M., Gabbianelli, G., Withycombe, G., and DomineyHowes, D. (2009). Assessing the vulnerability of buildings to tsunami in Sydney. Natural Hazards Earth System Sciences. Vol. 9, pp. 2015-2026. Copernicus Publications on behalf of the European Geosciences Union.

[12] Dalrymple, R. A., and Kriebel, D. L. (2005). Lessons in Engineering from the 'Tsunami in Thailand. The Bridge. Vol 35, Number 2, pp 4-13. National 'Academy Of Engineering.

[13] Diposaptono, S and Budiman. (2006). Tsunami. Buku Ilmiah Populer. Bogor.

[14] Dominey-Howes, D., and Papathoma, M. (2007). Validating a Tsunami Vulnerability Assessment Model (the PTVA Model) Using Field Data from the 2004 Indian Ocean Tsunami. Natural Hazards. Vol. 40, pp 113-136. Springer Netherlands.

[15] Ghobarah, A., Saatcioglu, M., and Nistor, I. (2006). The impact of the 26 December 2004 earthquake and tsunami on structures and infrastructure. Engineering Structures, Vol. 28, pp 312-326. Elsevier.

[16] Hajar, M. (2006). Pemetaan Tingkat Kerawanan Bencana Tsunami Menggunakan Data Pengindraan Jauh dan Sistem Informasi Geografi (SIG) Studi Kasus: Kota Padang. Minithesis. Marine Science and Technology Department, Bogor Agricultural University

[17] Honesti, L., Majid, M. Z. A., Muchlian, M., and Djali., N. (2014). Assessing Building Vulnerability to Tsunami Hazard in Padang. Jurnal Teknologi (Sciences \& Engineering). Vol. 69:6, pp 5-9. UTM Press.

[18] Honesti, L., Majid, M. Z. A., Djali., N., and Muchlian, M. (2015). Modeling the Potential Risk of Building Vulnerability toward Tsunami Hazard in Ulak Karang and Pasir Jambak Sub-District, Padang. Jurnal Teknologi (Sciences \& Engineering). Vol. 72:4, pp 41-47. UTM Press.

[19] Indonesia. (2002). Keputusan Menteri Permukiman dan Prasarana Wilayah tentang Pedoman teknis Pembangunan Gedung Negara. No.332/KPTS/M/2002.

[20] Indonesia. (2007). Peraturan Menteri Pekerjaan Umum tentang Pedoman Teknis Pembangunan Bangunan Gedung Negara. No: 45/PRT/M/2007.

[21] Indonesia. (2008). Peraturan Menteri Pekerjaan Umum tentang Pedoman Pemeliharaan dan Perawatan Bangunan Gedung. 24/PRT/M/2008.

[22] Iswanto, A. H. (2008). Audit Konstruksi Bangunan. Departemen Kehutanan Fakultas Pertanian. Universitas Sumatera Utara.

[23] Jelinek, R. Eckert, S., Zeug, G., and Krausmann, E. (2009). Tsunami Vulnerability and Risk Analysis Applied to the City of Alexandria, Egypt. Italy: European Commission.

[24] JICA, (2005). The Study on the Urgent Rehabilitation and Reconstruction Support Program 
for Aceh Province and Affected Areas in North Sumatra. Japan International Cooperation Agency (JICA), Badan Perencanaan Pembangunan Nasional (Bappenas), and Provincial Government of Nanggroe Aceh Darussalam, Banda Aceh.

[25] Kathiresan, K. and Rajendran, N. (2005). Coastal mangrove forests mitigated tsunami. Estuarine. Coastal and Shelf Science, Vol. 6. pp 601-606. Elsevier.

[26] Khasanah, L. U., Suwarsito,. Sarjanti, E. (2014). Tingkat Kerawanan Bencana Tsunami Kawasan Pantai Selatan Kabupaten Cilacap. Geoedukasi. Vol. III. No. 2. pp $77-82$. Universitas Muhammadiyah Purwokerto.

[27] Kikuchi, K., Hanazato, T., Kuroki, M., Koga, K., Kawakami, K., and Mita, N. (2012). Results of First Reconnaissance on Damage to Reinforced Masonry Buildings and Garden Walls Caused by the Great East Japan Earthquake in 2011. Proceedings of the International Symposium on Engineering Lessons Learned from the 2011 Great East Japan Earthquake. March 1-4. Tokyo, Japan.

[28] Kuwata, Y., \& Takada, S. (2004). Effective emergency transportation for saving human lives. Natural Hazards, Vol. 33, 23-46. Springer.

[29] Lekkas, E. L., Andreadakis, E., Kostaki, I., and Kapourani, E. (2013). A Proposal for a New Integrated Tsunami Intensity Scale (ITIS-2012). Bulletin of the Seismological Society of America. Vol. 103, No. 2B, pp. 1493-1502. Seismological Society of America.

[30] Matsutomi, H., Sakakiyama, T., Nugroho, S., and Matsuyama, M. (2006). Aspects of in inundated flow due to the 2004 Indian Ocean tsunami. Coastal Engineering Journal. Vol. 48, Issue 2, pp 167-195. World Scientific Publishing.

[31] Matsutomi, H., Okamoto, K., Harada, K. (2010). Inundation Flow Velocity of Tsunami on Land and its Practical Use. Proceedings of 32nd Conference on Coastal Engineering, Shanghai, China, No 32.

[32] Musa, Z. N., Popescu, I., Mynett, A (2014). The Niger Delta's vulnerability to river floods due to sea level rise. Nat. Hazard Earth Syst. Sc., 14,33173329-2014 www.Nat-hazards-earth-systsci.net/14/3317/2014/doi:10.5194/nhess-14-33172014@Author(s) 2014.CC Attribution 3.0 Licence.

[33] Najihah, R., Effendi, D. M., Hairunnisa, M. A., and Masiri, K. (2014). Tsunami vulnerability assessment mapping for the west coast of Peninsular Malaysia using a geographical information system (GIS). Earth and Environmental Science. Vol. 18. IOP Science.

[34] National Tsunami Hazard Mitigation Program. (2001). Designing for Tsunamis: Seven Principles for Planning and Designing for Tsunami Hazards.

[35] National Tsunami National Disaster Management Division Ministry of Home Affairs Government of India.(2006). Protection and Mitigation from Risk of Tsunami: a Strategy Paper.

[36] Pambudi, Y.S.S. (2014). Kerentanan Bangunan Hunian Pada Wilayah Zona Potensi Bencana Tsunami Di Kecamatan. Jurnal Pendidikan
Geografi Swara Bhumi. Vol 3, No 3. http://ejournal.unesa.ac.id

[37] Papathoma, M., and Dominey-Howes, D.(2003). Tsunami vulnerability assessment and its implications for coastal hazard analysis and disaster management planning, Gulf of Corinth, Greece. Natural Hazards and Earth System Sciences. Vol. 3, pp 733-747. European Geosciences Union.

[38] Putra, R. R., Kiyono, J., and Ono, Y. (2012). Shaking Characteristic of Padang City, Indonesia. $15^{\text {th }}$ World Conference on Earthquake Engineering (WCEE). Lisboa.

[39] Raskin, J., Wang, Y., Boyer, M.M., Fiez, T., Moncada, J., Yu, K., and Yeh, H. (2009). Preliminary White Paper on Tsunami Evacuation Buildings (TEBS): A New Risk Management Approach to Cascadia Earthquakes and Tsunamis. CBTEB 3-20-09 version.pdf

[40] Reese, S., Cousins, W. J., Power, W. L., Palmer, N. G., Tejakusuma, I. G., and Nugrahadi, S. (2007). Tsunami vulnerability of buildings and people in South Java - field observation after the July 2006 Java tsunami. Natural Hazards Earth System Sciences. Vol. 7, pp 573-589. Copernicus Publications on behalf of the European Geosciences Union.

[41] Rossetto, T., Peiris, N., Alarcon, JE., So, E., Sargeant, S., Free, M., and Sword-Daniels, V. (2009). The L'Aquila, Italy Earthquake of 6 April 2009. EEFIT Preliminary Field Report.

[42] Sandink, D. (2009). Handbook for reducing Basement flooding. Canada: ICLR (Institute for Catastrophic Loss Reduction).

[43] Sever, M., Vanholder, R., \& Lameire, N. (2006). Management of crash-related injuries after disasters. New England Journal of Medicine, Vol. 254, pp 1052-1063. http://www.nejm.org/

[44] Sivakumar, I., and Sivagamasundari, R. (2015). A Statistical Model for Assessing Building Vulnerability to Tsunami In Coastal Region. Asian Journal of Civil Engineering (BHRC). Vol. 16, No. 4, pp. 547-555. Building and Housing Research Center.

[45] Slotta-Bachmayr, L. (2005). How burial time of avalanche victims is influenced by rescue method: An analysis of search reports from the Alps. Natural Hazards, Vol. 34, pp. 341-352. Springer.

[46] Sumaryono. (2010). Assessing Building Vulnerability to Tsunami Hazard Using Integrative Remote Sensing and GIS Approaches. Dissertation Ludwig-Maximilians-Universität München.

[47] UNEP-SBCI. (2007). After the Tsunami: Sustainable building guidelines for South-East Asia, United Nations.

[48] UNESCO/IOC. (2012). A Guide to Tsunamis for Hotels: Tsunami Evacuation Procedures. http://neamtic.ioc-unesco.org/

[49] UNISDR. (2007). Handbook on Good Building Design and Construction Aceh and Nias Islands. United Nations. 
[50] Warnitchai, P. (2005). Lessons Learned from the 26 December 2004 Tsunami Disaster in Thailand. Proceedings of the 4th International Symposium on New Technologies for Urban Safety of Mega Cities in Asia. Singapore, 18-19 October.

[51] Wilson, S., McCloy, A., and Dea, A. O. (2013). Review of drainage and flooding implications of basement extensions in RBKC.
[52] Yudichara, 2008. Kaitan antara Karakteristika Pantai Propinsi Sumatera Barat dengan Potensi Kerawanan Tsunam. Jurnal Geologi Indonesia.3: 95-106 